\title{
Comparison of profile total ozone from SBUV (v8.6) with GOME-type and ground-based total ozone for a 16-year period (1996 to 2011)
}

\author{
E. W. Chiou ${ }^{1}$, P. K. Bhartia ${ }^{2}$, R. D. McPeters ${ }^{2}$, D. G. Loyola $^{3}$, M. Coldewey-Egbers ${ }^{3}$, V. E. Fioletov ${ }^{4}$, \\ M. Van Roozendael ${ }^{5}$, R. Spurr ${ }^{6}$, C. Lerot $^{5}$, and S. M. Frith \\ ${ }^{1}$ ADNET Systems, Inc., Lanham, MD 20706, USA \\ ${ }^{2}$ NASA Goddard Space Flight Center, Greenbelt, MD 20771, USA \\ ${ }^{3}$ German Aerospace Center (DLR), Oberpfaffenhofen, Germany \\ ${ }^{4}$ Environment Canada, North York, Ontario, Canada \\ ${ }^{5}$ Belgian Institute for Space Aeronomy, Brussels, Belgium \\ ${ }^{6}$ RT Solutions, Inc., Cambridge, MA 02138, USA \\ ${ }^{7}$ Science Systems and Applications, Inc., Lanham, MD 20706, USA \\ Correspondence to: E. W. Chiou (echiou@sesda3.com)
}

Received: 4 October 2013 - Published in Atmos. Meas. Tech. Discuss.: 27 November 2013

Revised: 24 April 2014 - Accepted: 28 April 2014 - Published: 11 June 2014

\begin{abstract}
This paper describes the comparison of the variability of total column ozone inferred from the three independent multi-year data records, namely, (i) Solar Backscatter Ultraviolet Instrument (SBUV) v8.6 profile total ozone, (ii) GTO (GOME-type total ozone), and (iii) ground-based total ozone data records covering the 16-year overlap period (March 1996 through June 2011). Analyses are conducted based on area-weighted zonal means for $0-30^{\circ} \mathrm{S}, 0-30^{\circ} \mathrm{N}$, $50-30^{\circ} \mathrm{S}$, and $30-60^{\circ} \mathrm{N}$.

It has been found that, on average, the differences in monthly zonal mean total ozone vary between -0.3 and $0.8 \%$ and are well within $1 \%$.

For GTO minus SBUV, the standard deviations and ranges (maximum minus minimum) of the differences regarding monthly zonal mean total ozone vary between $0.6-0.7 \%$ and $2.8-3.8 \%$ respectively, depending on the latitude band. The corresponding standard deviations and ranges regarding the differences in monthly zonal mean anomalies show values between $0.4-0.6 \%$ and $2.2-3.5 \%$. The standard deviations and ranges of the differences ground-based minus SBUV regarding both monthly zonal means and anomalies are larger by a factor of 1.4-2.9 in comparison to GTO minus SBUV.

The ground-based zonal means demonstrate larger scattering of monthly data compared to satellite-based records. The differences in the scattering are significantly reduced if seasonal zonal averages are analyzed.
\end{abstract}

The trends of the differences GTO minus SBUV and ground-based minus SBUV are found to vary between -0.04 and $0.1 \% \mathrm{yr}^{-1}\left(-0.1\right.$ and $\left.0.3 \mathrm{DU} \mathrm{yr}^{-1}\right)$. These negligibly small trends have provided strong evidence that there are no significant time-dependent differences among these multiyear total ozone data records.

Analyses of the annual deviations from pre-1980 level indicate that, for the 15-year period of 1996 to 2010, all three data records show a gradual increase at $30-60^{\circ} \mathrm{N}$ from $-5 \%$ in 1996 to $-2 \%$ in 2010 . In contrast, at $50-30^{\circ} \mathrm{S}$ and $30^{\circ} \mathrm{S}-$ $30^{\circ} \mathrm{N}$ there has been a levelling off in the 15 years after 1996 . The deviations inferred from GTO and SBUV show agreement within $1 \%$, but a slight increase has been found in the differences during the period 1996-2010.

\section{Introduction}

Concern for changes in the ozone layer due to human activity is an important subject for the scientific community, the general public and governments. Accurate long-term data records of total column ozone and vertical profiles of ozone are required for the scientific assessment of ozone depletion (WMO, 2011). 
In response to the observed ozone loss, countries around the world adopted the Montreal Protocol and subsequent amendments calling for limitations on production and use of ozone-depleting substances (UNEP, 2006; UNFCCC, 1998). Besides the impact of ozone depleting substances, natural fluctuations such as the 11-year solar cycle, the equatorial quasi-biennial oscillation of the lower stratospheric zonal wind (QBO), and volcanic eruptions also significantly affect the thickness of the ozone layer. Moreover, climate change due to increase in greenhouse gas concentration will influence stratospheric dynamics and chemistry and therefore the ozone layer. Many investigations have been conducted for monitoring and detection of global ozone trends and behavior using a variety of ground-based and satellite instruments and their comparisons. Recent studies based on long-term ozone data records and model simulations have significantly improved our understanding in the roles of various dynamical and chemical processes governing the ozone variations (e.g., Yang, 2006; Stolarski and Frith, 2006; WMO, 2011). However, many detail characteristics of the expected ozone recovery such as the beginning of the recovery and the timing of the recovery are still unclear. One of the major difficulties in assessing long-term global ozone variations is data inhomogeneity. Changes in operational satellites, revision of retrieval algorithms, recalibration of ground-based instruments or interruptions in observation periods result in data sets that have systematic errors that change with time.

The purpose of this study is to conduct an investigation of the consistency in the variability of global and zonal total ozone inferred from three independent multiyear data records, namely, (1) the recently released Solar Backscatter Ultraviolet Instrument (SBUV) v8.6 profile total ozone data record, (2) the new European GOMEtype total ozone record (GTO), and (3) ground-based total ozone data record based on Dobson and Brewer spectrometer and filter ozonometer observations available from the World Ozone and Ultraviolet Radiation Data Centre (WOUDC) (http://www.msc-smc-smc.ec.gc.ca/woudc/). The two satellite-based merged ozone data records (SBUV v8.6 and GTO) are the most recent versions released during 2012-2013. They represent the results of two independent attempts by US and European scientists to adopt an optimal technique to merge ozone measurements from a series of satellite instruments aiming to construct a homogeneous self-consistent and calibrated long-term data record.

The analyses are based on the 16-year overlap period of March 1996 through June 2011. Our major goal is to quantitatively evaluate the long-term stability of the global and zonal mean total column ozone from these three multi-year data records. Discussions will be focused on the consistency regarding monthly zonal mean total ozone and the monthly zonal mean anomalies. The results obtained herein should enable us to enhance our understanding of the accuracy of these multi-year data records.
Detailed information of the three data records is provided in Sect. 2. Results of comparisons based on 5-degree monthly zonal means between $60^{\circ} \mathrm{S}$ and $60^{\circ} \mathrm{N}$ are presented in Sect. 3.1. Further analysis using area-weighted monthly zonal means for $0-30^{\circ} \mathrm{S}, 0-30^{\circ} \mathrm{N}, 50-30^{\circ} \mathrm{S}$, and $30-60^{\circ} \mathrm{N}$ is discussed in Sects. 3.2 and 3.3. Changes that will occur when switching to analysis using seasonal zonal means are reported in Sect. 3.4. Trends of the differences are discussed in Sect. 3.5. Investigation of total ozone deviations from pre1980 levels is reported for $30-60^{\circ} \mathrm{N}, 50-30^{\circ} \mathrm{S}$, and $30^{\circ} \mathrm{S}-$ $30^{\circ} \mathrm{N}$ in Sect. 3.6. Concluding remarks from our study are summarized in Sect. 4.

\section{Description of the three ozone data records}

\subsection{SBUV v8.6 profile total ozone data record}

NASA and NOAA have been measuring ozone from space since 1970 . The previously existing merged ozone data set provided by NASA combines the TOMS data (Nimbus 7 and Earth Probe) and SBUV-SBUV/2 data (Nimbus 7, NOAA 9, $11,14,16)$. Studies were made by Stolarski and Frith (2006) using the merged ozone data set to search for evidence of ozone recovery in response to the observed levelling off of chlorine compounds in the stratosphere. Before v8.6, the philosophy for producing the merged data set was to take the individual data sets and combine them by making simple offset corrections in ozone based on overlap periods or comparisons with other data sets. The correction offset is determined as the average difference in the $50^{\circ} \mathrm{S}$ to $50^{\circ} \mathrm{N}$ zone. No time dependence is applied to an individual data set. All the monthly zonal means for an instrument are adjusted by a single offset. There is no latitudinal dependence applied. All data sets available for each month are then averaged together to produce the final merged ozone time series.

However, for v8.6 no global offsets or any offsets were applied to profile total ozone records from individual SBUV instruments before combining them. The inter-calibration is accomplished within the v8.6 algorithm (Frith et al., 2014). The SBUV v8.6 profile total ozone data record incorporated the measurements from eight backscatter ultraviolet instruments (BUV on Nimbus 4, SBUV on Nimbus 7, and a series of SBUV/2 instruments on NOAA satellites). The coverage periods of each instrument used to create the merged ozone data set are shown in Table 1. As described in Frith et al. (2014), pairs of the SBUV measurements records are combined using a simple average during periods when data from more than one instrument are present. The only exception is the exclusion outside the ECT (Equator crossing time) range of 8 a.m. to 4 p.m. and nearly all NOAA-9 data. Discussion of SBUV v8.6 algorithm is presented by Bhartia et al. (2013). An overview of the version 8.6 SBUV ozone data record is discussed by McPeters et al. (2013). Major improvement has been achieved by radiance adjustment made 
Table 1. Period of coverage by each instrument used in constructing the SBUV merged profile total ozone data record.

\begin{tabular}{lll}
\hline Satellite instrument & Period covered & Remarks \\
\hline Nimbus 4 BUV & May 1970-Apr 1976 & (All data) \\
Nimbus 7 SBUV & Nov 1978-May 1990 & (All data) \\
NOAA 11 SBUV/2 & Jan 1989-Mar 1995 & (Enter terminator orbit; 18:00 ECT) \\
NOAA 11 SBUV/2 & Oct 1997-Mar 2001 & (08:00 ECT; end of record) \\
NOAA 14 SBUV/2 & Mar 1995-Apr 2000 & (16:00 ECT; nearing terminator) \\
NOAA 14 SBUV/2 & Jul 2004-Sep 2006 & (08:00 ECT; end of record) \\
NOAA 16 SBUV/2 & Oct 2000-Jun 2007 & (16:00 ECT; nearing terminator) \\
NOAA 16 SBUV/2 & Dec 2011-Dec 2011 & (08:00 ECT) \\
NOAA 17 SBUV/2 & Aug 2002-Sep 2011 & (08:00 ECT; nearing terminator) \\
NOAA 18 SBUV/2 & Jul 2005-Dec 2011 & \\
\hline
\end{tabular}

* ECT: Equator crossing time.

for each instrument to maintain a consistent calibration (DeLand et al., 2012). This new merged ozone data record covers the period from 1970 to 2011. Two other important changes in the processing of v8.6 are that the ozone cross sections of Brion, Daumont and Malicet have been used and that a cloud climatology derived from the Aura/OMI (Ozone Monitoring Instrument) cloud-height retrievals has been used (Bhartia et al., 2013).

Results of the study for the effect of applying the new cross sections to SBUV retrievals indicate that the ozone profiles are lower in the upper stratosphere and higher in the lower stratosphere and troposphere. As a result, the average differences in total ozone are small, and close to zero in the tropics (McPeters and Labow, 2010).

Recent studies of the differences in total ozone between v8.6 and v8.0 (Merged Ozone Data Sets) MODs indicate that v8.6 is 0.5 to $1 \%$ lower than v8.0 at all times except in the mid-1990s, when v8.6 is $1 \%$ higher. The difference in mid-1990 is related to the use of NOAA-14 in the new version rather than the NOAA-9 used in the v8.0 MOD product. The deviation in mid-1982 results from different treatment of the data after the eruption of El Chichón in late March 1982 (Frith et al., 2014).

\subsection{GTO ozone data record}

The European satellite-borne sensors GOME/ERS-2 (19952011), SCIAMACHY/ENVISAT (2002-2012), and GOME2/METOP-A (2007-present) provide global total ozone measurements for the last $17 \mathrm{yr}$. A summary of the instrument properties and viewing geometries is given in Table 2 .

The GTO merged ozone data record combines those measurements, and a continuous and homogeneous monthly mean time series is generated (Loyola et al., 2009; Loyola and Coldewey-Egbers, 2012). The first GTO version was created using products obtained with the GOME Data Processor (GDP) version 4.x algorithm (Van Roozendael et al., 2006; Lerot et al., 2009; Loyola et al., 2011), which is based on the differential optical absorption spectroscopy approach. Geophysical validation shows that GDP 4.x total ozone has an accuracy at the percentage level compared with ground-based instruments (Loyola et al., 2011; Koukouli et al., 2012). The resulting GTO data record was used for the WMO ozone assessment report 2010 (WMO, 2011) and for ozone studies (Dameris and Loyola, 2012).

In this study we use the most recent version of the GTO data record that has been developed within the framework of the European Space Agency's Climate Change Initiative (ESA-CCI). It incorporates the ozone data products retrieved using the newly developed GOME Direct Fitting algorithm GODFIT (Lerot et al., 2010, 2014; Van Roozendael et al., 2012) and covers the period from March 1996 to June 2011.

The GTO merging approach accounts for the generally small remaining differences among the individual instruments, which mainly depend on latitude, season, and time. Due to excellent long-term stability, the GOME measurements are used as a transfer standard, whereas SCIAMACHY and GOME-2 data are adjusted accordingly in periods of instrument overlap (Loyola et al., 2009). The adjustments comprise two parts: a basic latitudinal correction for each month of the year averaged over all years and a time-dependent offset for each individual month. Within the ESA-CCI the merging approach has been further improved; the adjustment is now based on daily averages (instead of monthly) in order to reduce differences among the individual instruments due to differences in spatial and temporal sampling (see Table 2). The daily averages now incorporate all available measurements from one day, which increases the number of observations at high latitudes where the orbits overlap. Monthly averages are computed taking into account latitudinal and seasonal constraints in order to provide representative mean values. Finally, GOME, adjusted SCIAMACHY and adjusted GOME-2 data are merged.

\subsection{Ground-based ozone data record}

The World Ozone and Ultraviolet Radiation Data Centre (WOUDC) in Toronto began collecting and publishing ozone 
Table 2. Characteristics of the three European satellite instruments.

\begin{tabular}{llll}
\hline Parameter & GOME & SCIAMACHY & GOME-2 \\
\hline Data availability & Jul 1995-Jun 2011* & Aug 2002-Mar 2012 & Jan 2007-today \\
Spectral coverage & $240-790 \mathrm{~nm}$ & $240-2380 \mathrm{~nm}$ & $240-790 \mathrm{~nm}$ \\
Spectral resolution & $0.2-0.4 \mathrm{~nm}$ & $0.2-1.5 \mathrm{~nm}$ & $0.2-0.4 \mathrm{~nm}$ \\
Ground pixel size & $320 \times 40 \mathrm{~km}^{2}$ & $60 \times 30 \mathrm{~km}^{2}$ & $40 \times 80 \mathrm{~km}^{2}$ \\
Swath width & $960 \mathrm{~km}$ & $960 \mathrm{~km}$ & $1920 \mathrm{~km}$ \\
Equator crossing & $10: 30 \mathrm{LT}$ & $10: 00 \mathrm{LT}$ & $09: 30 \mathrm{LT}$ \\
Global coverage & 3 days & 6 days & almost daily \\
\hline
\end{tabular}

* No global coverage since June 2003.

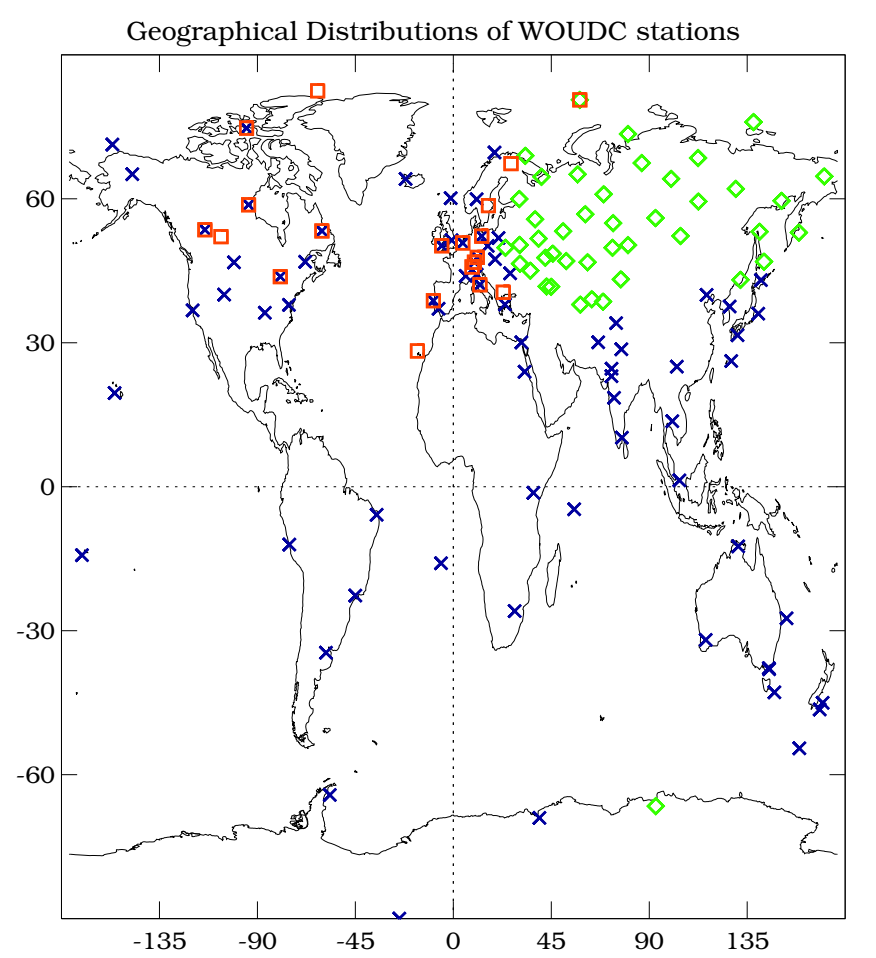

Dobson Stations

Brewer Stations

\section{Filter Instrument Stations}

Figure 1. Geographical distributions of WOUDC ground stations.

data in 1961 and remains the main source of ground-based ozone data for researchers. Global distributions of groundbased stations used in this study are depicted in Fig. 1. Large longitudinal inhomogeneity and limited spatial coverage make it impossible to estimate zonal and global total ozone values from station values directly. However, if an ozone "climatology" (i.e., long-term mean for each point of the globe for each day of the year) estimated from satellite data is used with ground-based measurements of ozone deviations from that climatology at the stations, then long-term zonal and global ozone variations can be estimated using ground-based data (Bojkov and Fioletov, 1995). The present climatology used is based on TOMS N7 version 8 for the 1978-1987 period everywhere except for the Antarctic, where 1978-1982 data only were used. The climatology was last updated in 2004. In summary, the method measures ozone deviations from the climatology at the stations, then calculates the zonal deviations, and finally the zonal mean ozone is determined by adding the zonal mean climatology to the zonal means of the deviations. The results give a continuous uninterrupted global total ozone data record that is fairly independent of other data sources.

However, the absence of data over vast regions (e.g., oceans) and sensitivity to individual instrument errors is an important factor, particularly in the tropical region and the Southern Hemisphere where the number of stations is very limited. Comparisons of global and zonal ozone variations from ground-based and satellite measurements for the period 1964-2000 were presented by Fioletov et al. (2002). The ground-based multi-year total ozone record used in this study is the recently updated one extending through November 2012 .

\section{Results and discussions}

Even though the most recently released SBUV (v8.6) ozone profile and ground-based total ozone data records cover a 43-year period (1970-2012) and a 49-year period (19642012), respectively, our studies focus on the 16-year period (March 1996 to June 2011) for which these two data records overlap with GTO. For high-latitude regions, the number of ground stations is very limited to represent the characteristics of the latitudinal zones. It is also known that the available number of SBUV measurements is drastically reduced in the high-latitude regions in both hemispheres. For example, as shown in Fig. 2, among the 184 months (from March 1996 to June 2011) selected for this study, more than $20 \%$ of the months are missing data poleward of $60^{\circ} \mathrm{S}$ and $65^{\circ} \mathrm{N}$ in SBUV (v8.6) data records. Thus, our analyses and comparisons will only be based on the 245 -degree monthly zonal mean time series (covering $60^{\circ} \mathrm{S}$ to $60^{\circ} \mathrm{N}$ ) from these three multi-year data records. 


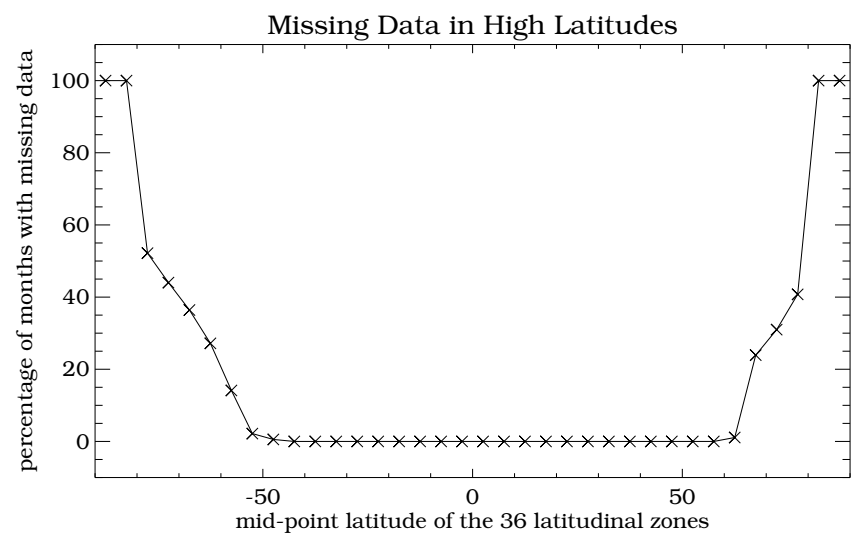

Figure 2. Missing data in high latitudes for SBUV v8.6.

\subsection{The 5-degree monthly zonal means between $60^{\circ} \mathrm{S}$ and $60^{\circ} \mathrm{N}$}

Figure $3 \mathrm{a}-\mathrm{c}$ show the monthly mean zonal mean total column ozone as a function of latitude and time given by SBUV v8.6, GTO and ground-based data records, respectively. Black regions in Fig. 3a represent missing data in SBUV. The features revealed in these figures clearly indicate that the three data records exhibit almost identical patterns of temporal and latitudinal variations for the entire 16-year period.

The differences (in \%) between each pair of data records are illustrated in Fig. 4a-c. Black regions in Fig. 4a and b represent missing data in SBUV. The agreement between the two satellite-based ozone data records is significantly better than the agreement between each satellite data record and the ground-based record. Statistical parameters for the percentage differences revealed in these figures are listed in Table $3 \mathrm{a}-\mathrm{c}$.

After a more detailed investigation of the three data records, it has been found that the monthly zonal mean at $60-55^{\circ} \mathrm{S}$ from ground-based record has an obvious outlier appearing at one particular month - November 2009. Thus, we have intentionally excluded that particular data point in deriving the statistical parameters listed in Table $3 \mathrm{~b}$ and $\mathrm{c}$. The entries with an asterisk listed in the first row in Table $3 \mathrm{~b}$ and c would increase to 27.6 and $28.3 \%$ respectively without excluding this data point.

Major findings from Table 3a-c can be summarized as follows:

1. For both GTO versus SBUV and satellite-based record versus ground-based record, the standard deviations and the ranges (maximum minus minimum, representing peak-to-peak variations) of the differences are similar for $0-30^{\circ} \mathrm{S}, 0-30^{\circ} \mathrm{N}$, and $30-60^{\circ} \mathrm{N}$ and are much smaller than those at $30-60^{\circ} \mathrm{S}$.

2. The standard deviations of the differences between the two satellite-based records vary between 0.7 and $1.0 \%$. (a) SBUV Data Record

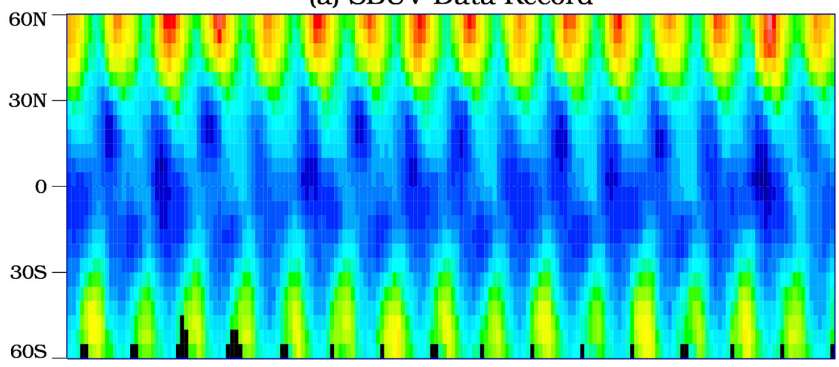

(b) GTO(GOME Type total ozone version 2)

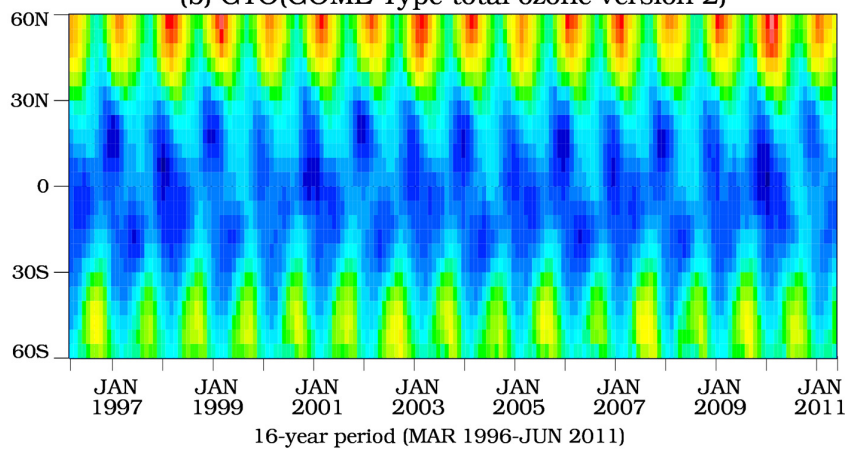

total ozone (DU)

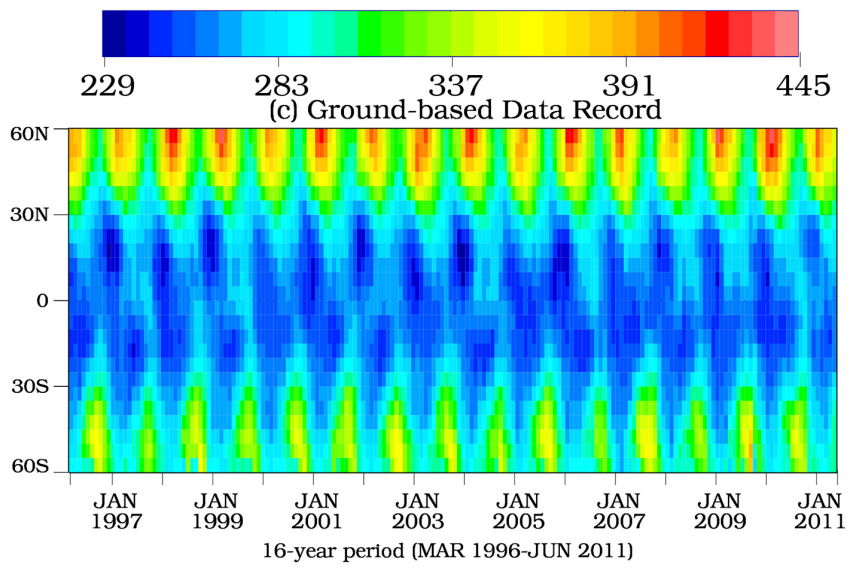

total ozone (DU)

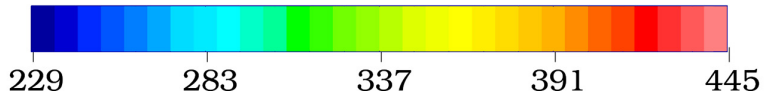

Figure 3. Monthly mean zonal mean total column ozone (5degree zones): (a) SBUV, (b) GTO (GOME-type total ozone), and (c) ground-based data record. (Black regions represent missing data in SBUV v8.6.)

The corresponding standard deviations for satellitebased record versus ground-based record are significantly larger, ranging between 1.4 and $2.1 \%$.

3. The ranges of the differences GTO minus SBUV vary between 3.9 and $9.9 \%$. The corresponding ranges of the differences for ground-based record versus satellitebased record are larger by a factor of 2 to 3 . 


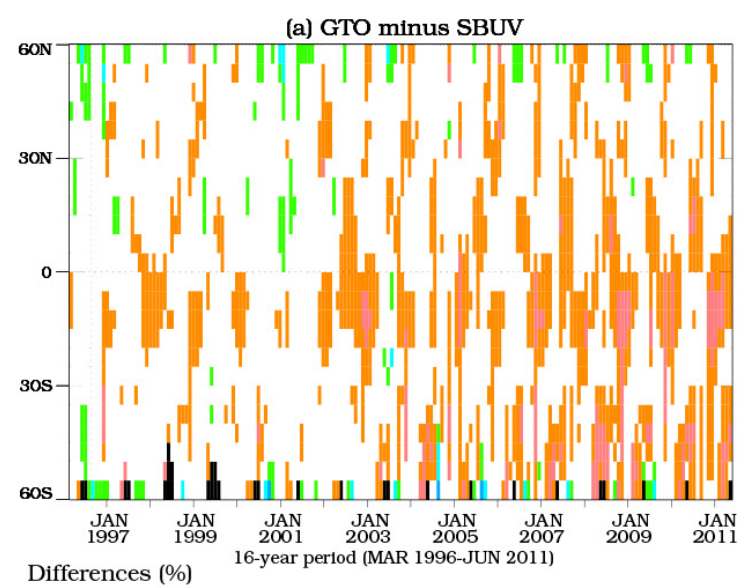

Differences (\%)
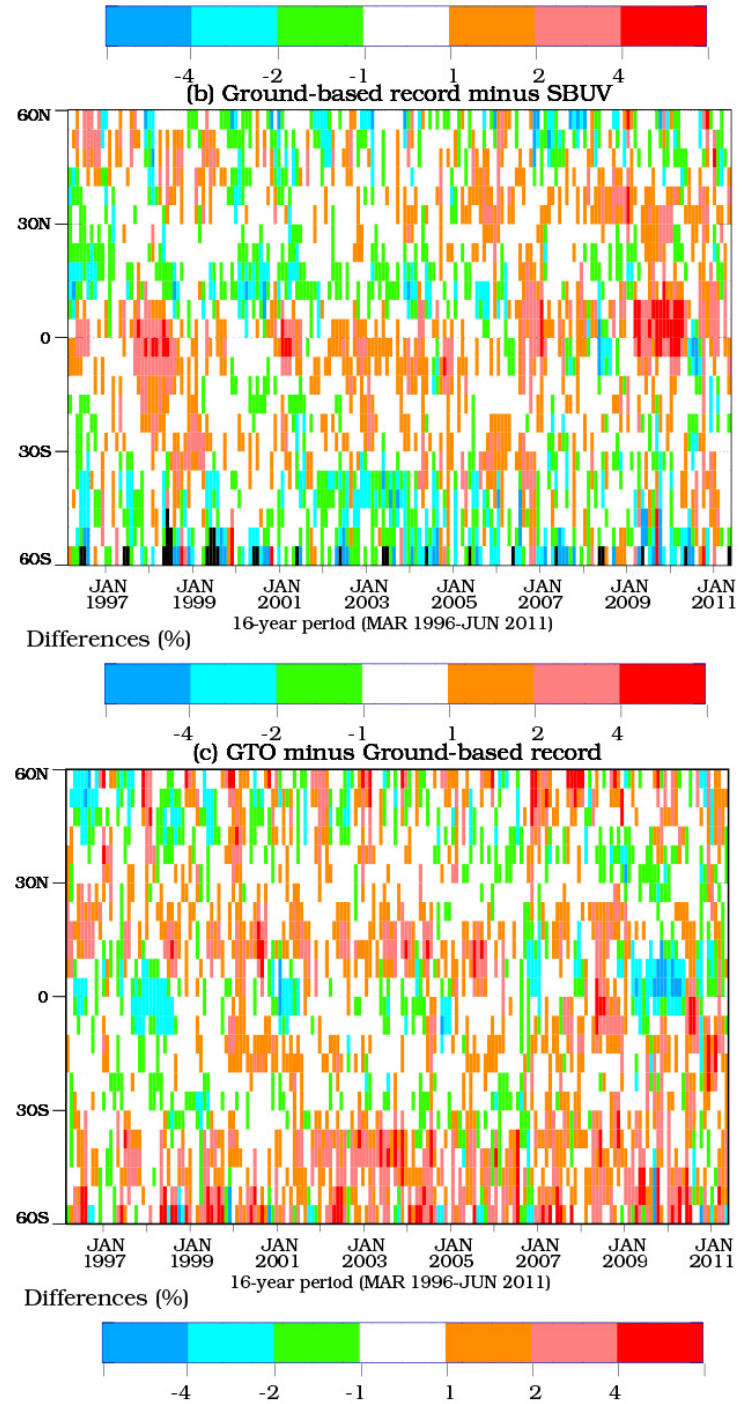

Figure 4. Differences in monthly zonal means (5-degree zones): (a) GTO minus SBUV, (b) ground-based minus SBUV, and (c) GTO minus ground-based. (Black regions represent missing data in SBUV v8.6.)
Table 3. Summary of the differences in monthly zonal mean total ozone.

\begin{tabular}{lrrr}
\hline \multicolumn{2}{l}{ (a) GTO minus SBUV } \\
\hline \multirow{2}{*}{ Latitudinal zones } & \multicolumn{3}{c}{ Differences in percent } \\
\cline { 2 - 4 } & Mean & Standard deviations & Range (Max-Min) \\
\hline$\left(30-60^{\circ} \mathrm{S}\right)$ & 0.55 & 0.98 & 9.87 \\
$\left(0-30^{\circ} \mathrm{S}\right)$ & 0.74 & 0.75 & 5.65 \\
$\left(0-30^{\circ} \mathrm{N}\right)$ & 0.43 & 0.70 & 3.96 \\
$\left(30-60^{\circ} \mathrm{N}\right)$ & 0.18 & 0.78 & 6.47
\end{tabular}

(b) Ground-based minus SBUV

\begin{tabular}{lrrr}
\hline \multirow{2}{*}{ Latitudinal zones } & \multicolumn{3}{c}{ Differences in percent } \\
\cline { 2 - 4 } & Mean & Standard deviations & Range (Max-Min) \\
\hline$\left(30-60^{\circ} \mathrm{S}\right)$ & -0.61 & 2.07 & $19.17^{*}$ \\
$\left(0-30^{\circ} \mathrm{S}\right)$ & 0.56 & 1.37 & 11.32 \\
$\left(0-30^{\circ} \mathrm{N}\right)$ & 0.10 & 1.67 & 12.71 \\
$\left(30-60^{\circ} \mathrm{N}\right)$ & 0.67 & 1.56 & 12.04 \\
\hline
\end{tabular}

\begin{tabular}{lrrr}
\hline \multicolumn{2}{l}{ (c) GTO minus ground-based } \\
\hline \multirow{2}{*}{ Latitudinal zones } & \multicolumn{3}{l}{ Differences in percent } \\
\cline { 2 - 4 } & Mean & Standard deviations & Range (Max-Min) \\
\hline$\left(30-60^{\circ} \mathrm{S}\right)$ & 1.21 & 2.13 & $19.89^{*}$ \\
$\left(0-30^{\circ} \mathrm{S}\right)$ & 0.19 & 1.39 & 12.72 \\
$\left(0-30^{\circ} \mathrm{N}\right)$ & 0.33 & 1.62 & 12.42 \\
$\left(30-60^{\circ} \mathrm{N}\right)$ & 0.11 & 1.66 & 12.18 \\
\hline
\end{tabular}

* One outlier data point from ground-based record (November 2009; 60-55 $\mathrm{S}$ ) was excluded.

\subsection{Area-weighted monthly mean zonal means for broader latitudinal zones}

In order to examine the characteristics of the differences between pairs of data records for several wider latitudinal zones, we have computed the area-weighted monthly mean zonal mean time series for (i) $0-30^{\circ} \mathrm{S}$, (ii) $0-30^{\circ} \mathrm{N}$, (iii) 50 $30^{\circ} \mathrm{S}$, and (iv) $30-60^{\circ} \mathrm{N}$. For the Southern Hemisphere, areaweighted means are limited to equatorward of $50^{\circ} \mathrm{S}$ due to a large number of months (namely, 26 months) with missing data in the SBUV v8.6 data record. The monthly mean zonal mean time series for these four broad latitudinal zones are plotted in Fig. 5. The corresponding differences, with respect to SBUV, are illustrated in Fig. 6. The statistical parameters corresponding to these differences are summarized in Table 4.

For the ground-based minus SBUV differences, there are two periods, namely, beginning of 2007 and end of 2009 where the differences show larger positive deviations in the $0-30^{\circ} \mathrm{N}$ band. Figure $6 \mathrm{c}$ and $\mathrm{d}$ also indicate that the differences GTO minus SBUV show slight changes from negative difference in 1996 to positive differences in the second half of the period. An explanation of these features is not readily available and further investigation in this regard is worthwhile once revised data records become available in the near future. 
Table 4. Summary of the differences in monthly zonal mean total ozone (four broad latitudinal zones).

\begin{tabular}{lrrrrrrr}
\hline \multirow{2}{*}{$\begin{array}{l}\text { Latitudinal } \\
\text { zones }\end{array}$} & \multicolumn{2}{c}{ GTO minus SBUV (in \%) } & & \multicolumn{3}{c}{ Ground-based minus SBUV (in \%) } \\
\cline { 2 - 3 } & Mean & $\begin{array}{r}\text { Standard } \\
\text { deviation }\end{array}$ & $\begin{array}{c}\text { Range } \\
\text { (Max-Min) }\end{array}$ & & Mean & $\begin{array}{c}\text { Standard } \\
\text { deviation }\end{array}$ & $\begin{array}{r}\text { Range } \\
\text { (Max-Min) }\end{array}$ \\
\hline$\left(0-30^{\circ} \mathrm{S}\right)$ & 0.76 & 0.63 & 3.63 & & 0.56 & 0.91 & 5.14 \\
$\left(0-30^{\circ} \mathrm{N}\right)$ & 0.43 & 0.58 & 2.83 & & 0.10 & 1.12 & 6.92 \\
$\left(50-30^{\circ} \mathrm{S}\right)$ & 0.67 & 0.66 & 3.82 & & -0.32 & 1.23 & 5.75 \\
$\left(30-60^{\circ} \mathrm{N}\right)$ & 0.20 & 0.63 & 3.35 & & 0.09 & 0.98 & 6.31 \\
\hline
\end{tabular}
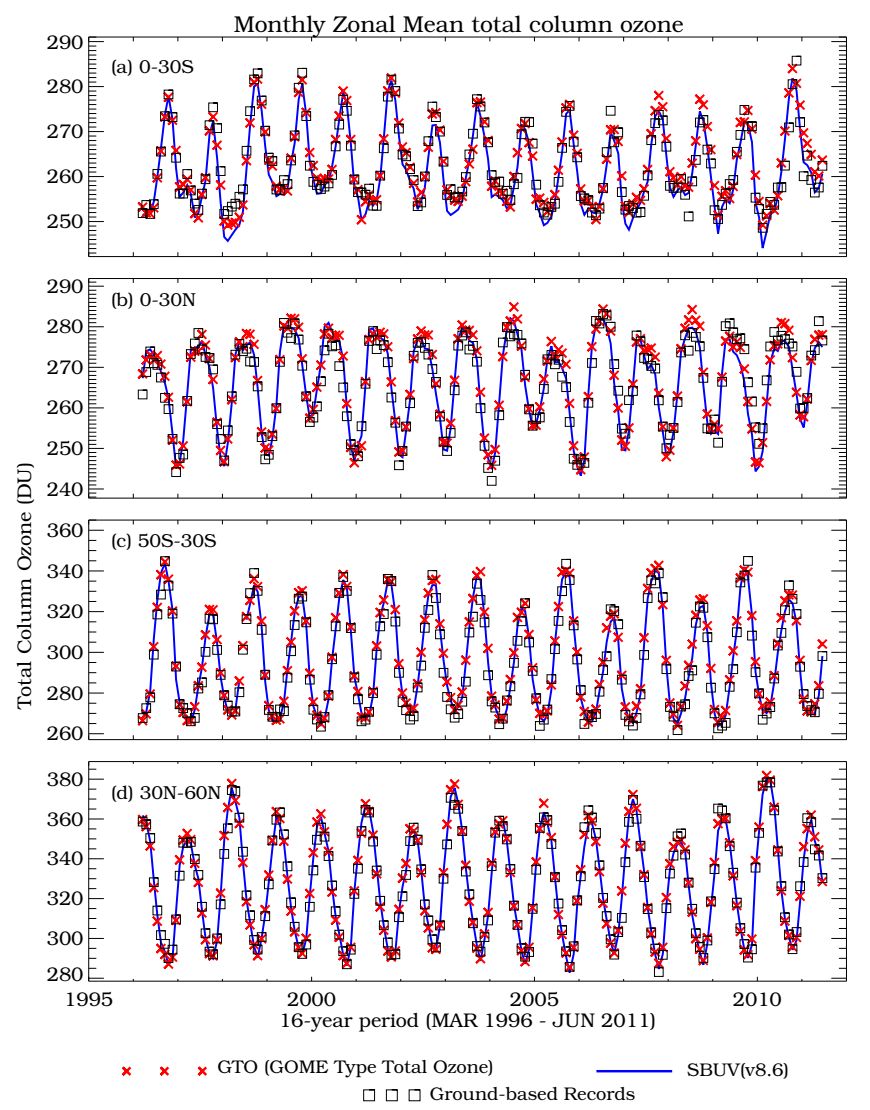

Figure 5. Monthly mean zonal mean total ozone (area-weighted zonal means for broader latitudinal zones).

The entries of mean differences in Table 4 have led to the conclusion that, on average, the differences of monthly mean zonal mean total ozone between the two satellite records and between satellite record and ground-based record vary between -0.3 and $0.8 \%$ and are well within $1 \%$. The longterm stability of the differences during the 16-year period is revealed by the standard deviations and ranges listed in Table 4. The standard deviations for GTO minus SBUV are found to lie between 0.6 and $0.7 \%$, while ground-based minus SBUV exhibits less stability with standard variations varying between 0.9 and $1.2 \%$. The ranges of the differences for GTO minus SBUV vary between 2.8 and $3.8 \%$. It is also
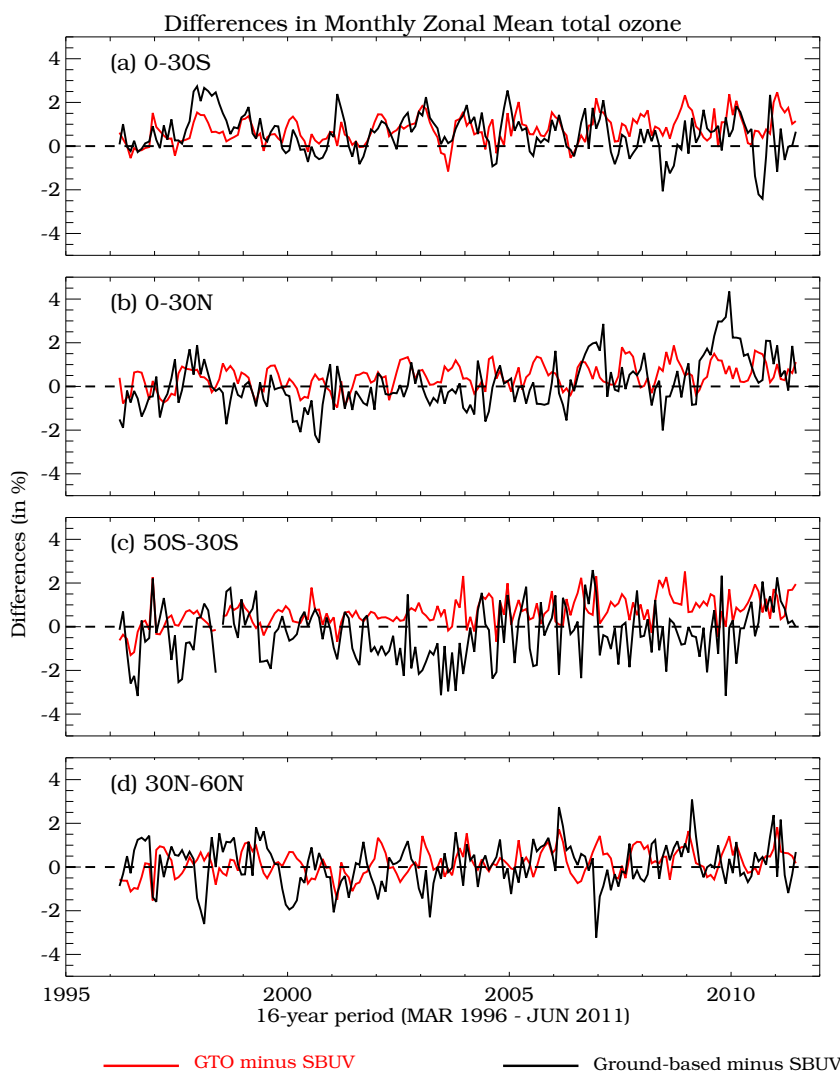

Figure 6. Differences in monthly mean zonal mean total ozone.

noticed that the corresponding ranges of the differences for ground-based minus SBUV are larger by a factor of 1.4 to 2.4 , varying between 5.1 and $6.9 \%$.

\subsection{Monthly mean zonal mean anomaly}

The consistency among the data records in terms of interannual variations in total ozone can be examined through investigation of the monthly mean zonal mean anomaly. For each of the three data records, the monthly mean zonal mean anomaly is calculated by simply subtracting the 16-year average for the same calendar month from the monthly mean zonal mean total ozone. The times series of monthly mean zonal mean anomaly for the four broad zonal bands are plot- 


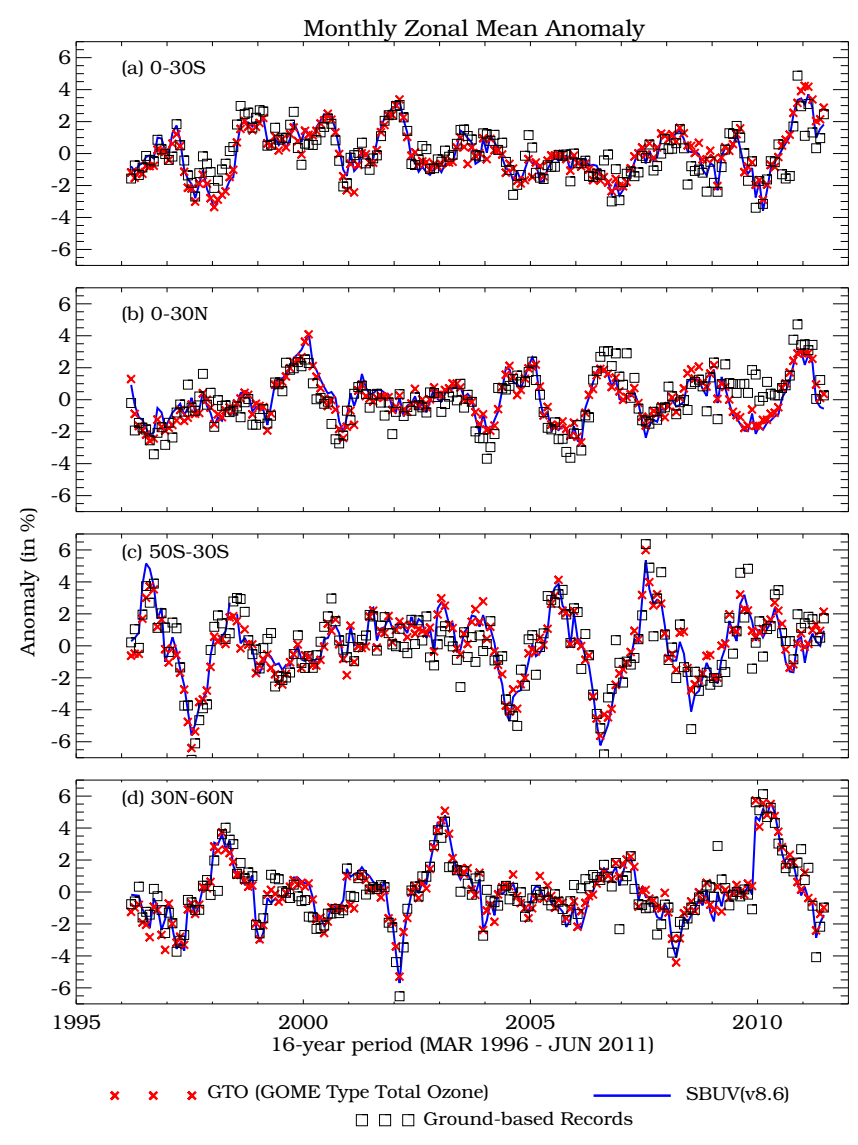

Figure 7. Monthly mean zonal mean anomaly.

ted in Fig. 7. The corresponding differences, with respect to SBUV, are illustrated in Fig. 8. The statistical parameters corresponding to these differences are listed in Table 5. The standard deviations of the differences for GTO minus SBUV vary between 0.4 and $0.6 \%$, and the corresponding values for ground-based minus SBUV are larger by a factor of 1.8 to 2.6. The anomalies inferred from GTO and SBUV show very good agreement, with ranges of the differences varying between 2.2 and $3.5 \%$. The corresponding ranges for ground-based minus SBUV exhibit larger scattering with values ranging between 4.4 and $6.3 \%$.

\subsection{Seasonal mean zonal mean and anomaly}

It is generally acknowledged that the poor spatial sampling and the relatively infrequent measurements could be the major factors causing the differences between ground-based and satellite monthly mean zonal mean total ozone data. To further explore evidence supporting such an argument, we have conducted additional analysis for the comparisons of GTO versus SBUV and ground-based versus SBUV using the seasonal mean zonal means instead of the monthly mean zonal means. For each of the three data records, 61 seasonal mean zonal means were computed starting from MAM

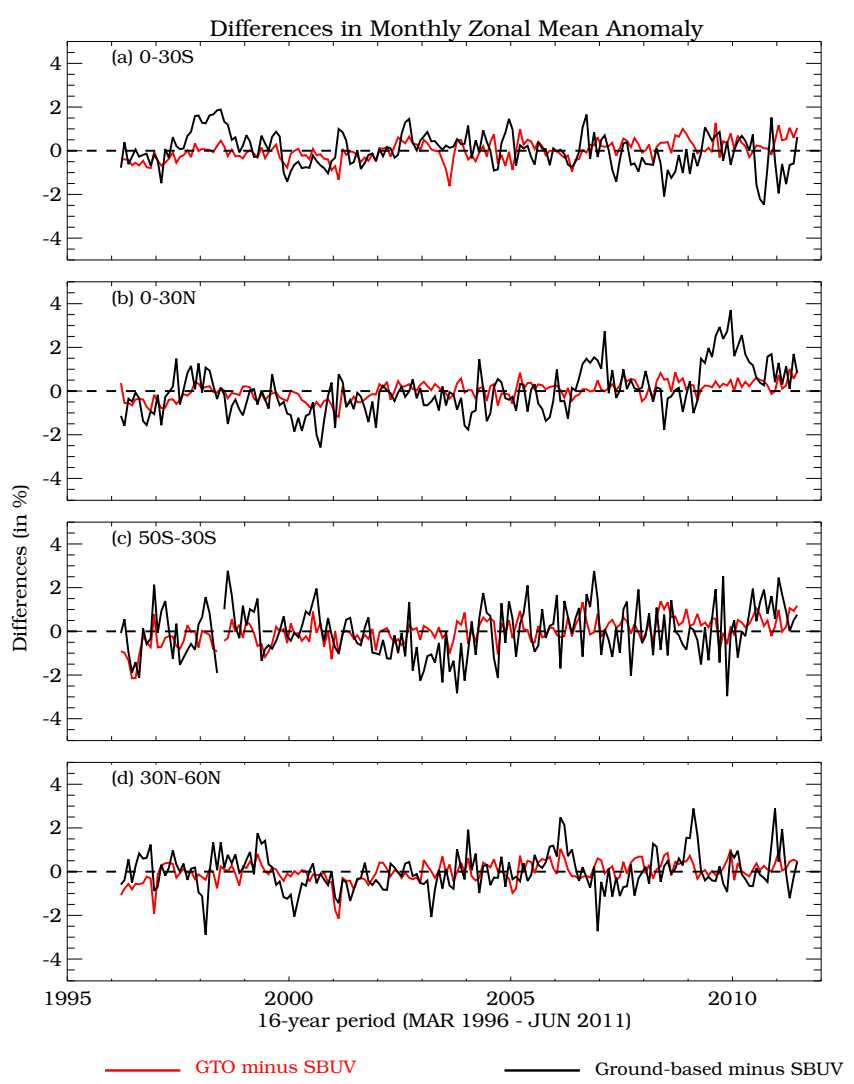

Figure 8. Differences in monthly mean zonal mean anomaly.

(March-April-May) in 1996 until MAM in 2011. Results of the differences in seasonal mean zonal means and in seasonal mean zonal mean anomalies are summarized in Tables 6 and 7 , respectively. The entries with brackets in these tables denote the reduction of each parameter compared to the corresponding values in Tables 4 and 5, which are based on monthly mean zonal means. The results in Tables 6 and 7 clearly indicate that the reduction in both the standard deviations and the ranges of the differences for ground-based $\mathrm{mi}-$ nus SBUV, when switching from monthly mean zonal means to seasonal mean zonal means, are found to significantly exceed the corresponding reduction for GTO minus SBUV.

These results have led to the conclusion that ground-based zonal means, while showing no systematic differences with respect to satellite-based data records, show larger scatter in monthly mean data compared to satellite-based records. The differences in the scattering are significantly reduced if seasonal zonal averages are analyzed.

\subsection{Trend of differences with respect to satellite data records}

Another approach to examine the consistency in the variability of total ozone exhibited by the multi-year data records is to investigate whether there is any time dependency in their differences. In this regard, we have computed the linear 
Table 5. Summary of the differences in monthly zonal mean anomaly (four broad latitudinal zones).

\begin{tabular}{lrrrrr}
\hline Latitudinal & \multicolumn{2}{c}{ GTO minus SBUV (in \%) } & & \multicolumn{2}{c}{ Ground-based minus SBUV (in \%) } \\
\cline { 2 - 2 } zones & $\begin{array}{c}\text { Standard } \\
\text { deviation }\end{array}$ & $\begin{array}{r}\text { Range } \\
\text { (Max-Min) }\end{array}$ & & $\begin{array}{c}\text { Standard } \\
\text { deviation }\end{array}$ & $\begin{array}{r}\text { Range } \\
\text { (Max-Min) }\end{array}$ \\
\hline$\left(0-30^{\circ} \mathrm{S}\right)$ & 0.45 & 2.89 & & 0.79 & 4.35 \\
$\left(0-30^{\circ} \mathrm{N}\right)$ & 0.40 & 2.19 & & 1.06 & 6.29 \\
$\left(50-30^{\circ} \mathrm{S}\right)$ & 0.59 & 3.53 & & 1.16 & 5.74 \\
$\left(30-60^{\circ} \mathrm{N}\right)$ & 0.47 & 3.19 & & 0.87 & 5.79 \\
\hline
\end{tabular}

Table 6. Summary of the differences in seasonal zonal mean total ozone (four broad latitudinal zones).

\begin{tabular}{|c|c|c|c|c|c|c|}
\hline \multirow{2}{*}{$\begin{array}{l}\text { Latitudinal } \\
\text { zones }\end{array}$} & \multicolumn{3}{|c|}{ GTO minus SBUV (in \%) } & \multicolumn{3}{|c|}{ Ground-based minus SBUV (in \%) } \\
\hline & Mean & $\begin{array}{l}\text { Standard } \\
\text { deviation }\end{array}$ & $\begin{array}{r}\text { Range } \\
(\text { Max-Min) }\end{array}$ & Mean & $\begin{array}{r}\text { Standard } \\
\text { deviation }\end{array}$ & $\begin{array}{r}\text { Range } \\
\text { (Max-Min) }\end{array}$ \\
\hline \multirow[t]{2}{*}{$\left(0-30^{\circ} \mathrm{S}\right)$} & 0.76 & 0.55 & 2.72 & 0.56 & 0.73 & 3.82 \\
\hline & & $(0.08)$ & $(0.91)$ & & $(0.18)$ & $(1.32)$ \\
\hline \multirow[t]{2}{*}{$\left(0-30^{\circ} \mathrm{N}\right)$} & 0.43 & 0.48 & 1.99 & 0.10 & 0.97 & 4.60 \\
\hline & & $(0.10)$ & $(0.84)$ & & $(0.15)$ & $(2.33)$ \\
\hline \multirow[t]{2}{*}{$\left(50-30^{\circ} \mathrm{S}\right)$} & 0.67 & 0.49 & 2.74 & -0.33 & 0.89 & 4.51 \\
\hline & & $(0.17)$ & $(1.08)$ & & $(0.34)$ & $(1.25)$ \\
\hline \multirow[t]{2}{*}{$\left(30-60^{\circ} \mathrm{N}\right)$} & 0.20 & 0.54 & 2.21 & 0.10 & 0.79 & 3.66 \\
\hline & & $(0.09)$ & $(1.14)$ & & $(0.19)$ & $(2.65)$ \\
\hline
\end{tabular}

The entries in brackets represent the reduction compared to analysis based on monthly zonal means.

trends using the differences of monthly mean zonal means for GTO minus SBUV and ground-based minus SBUV represented by the red curve and black curve depicted in Fig. 6 . The trends of differences for the four zonal bands are listed in Table 8a in terms of percent per year. The corresponding trends in DU per year are listed in Table 8b. These results have provided strong evidence that both the differences GTO minus SBUV and ground-based minus SBUV show no significant trends for the 16-year period (1996-2011) under investigation.

Quantitatively speaking, the trends are found to vary between -0.04 and $0.1 \% \mathrm{yr}^{-1}$ or -0.1 and $0.3 \mathrm{DU} \mathrm{yr}^{-1}$. The slightly larger trends for the differences of ground-based minus SBUV at $0-30^{\circ} \mathrm{N}$ are mainly driven by the high bias of ground-based data points in early 2010 as indicated by the black curve in Fig. 6b. Future updates of the ground-based data record might achieve further improvement in this aspect.

\subsection{Deviations from pre-1980 level}

Even though the investigation of ozone trends is beyond the scope of this paper, it is still interesting to examine the deviations of total column ozone from pre-1980 levels inferred from the three multi-year data records. Since a substantial part of ozone variability is related to QBO and the 11-year solar cycle (Bowman, 1989; Hamilton, 1989; Bojkov and Fioletov, 1996), removing these natural components from the data records will make it easier to examine the long-term changes. Our analysis to achieve this purpose was conducted as follows:

i. A regression model fit was performed using the groundbased monthly zonal mean total ozone time series covering 1964-2011. The model includes the annual cycle, EESC (effective equivalent stratospheric chlorine)related trend, solar-cycle-related component (using solar flux at $10.7 \mathrm{~cm}$ ), QBO-related component (using the normalized equatorial wind at 30 and $50 \mathrm{hPa}$ ), and volcanic component (using stratospheric optical depth at $550 \mathrm{~nm}$, only for the year following El Chichón and Pinatubo eruptions).

ii. The QBO-related and solar-cycle-related variations obtained from step (i) were subtracted from all three data records.

The annual deviations from pre-1980 levels are computed and depicted in Fig. 9a-c for $30-60^{\circ} \mathrm{N}, 50-30^{\circ} \mathrm{S}$, and $30^{\circ} \mathrm{S}-$ $30^{\circ} \mathrm{N}$, respectively. Pre-1980 annual zonal means based on 1964-1980 ground-based data record are used as our baseline.

It is noted that all three data records show consistent patterns of year-to-year changes for the three zonal bands. 
Table 7. Summary of the differences in seasonal zonal mean anomaly (four broad latitudinal zones).

\begin{tabular}{lrrrrr}
\hline \multirow{2}{*}{$\begin{array}{l}\text { Latitudinal } \\
\text { zones }\end{array}$} & \multicolumn{2}{c}{ GTO minus SBUV (in \%) } & & \multicolumn{2}{c}{ Ground-based minus SBUV (in \%) } \\
\cline { 2 - 3 } & $\begin{array}{c}\text { Standard } \\
\text { deviation }\end{array}$ & $\begin{array}{r}\text { Range } \\
\text { (Max-Min) }\end{array}$ & & $\begin{array}{c}\text { Standard } \\
\text { deviation }\end{array}$ & $\begin{array}{r}\text { Range } \\
\text { (Max-Min) }\end{array}$ \\
\hline$\left(0-30^{\circ} \mathrm{S}\right)$ & 0.38 & 1.76 & & 0.62 & 3.09 \\
& $(0.07)$ & $(1.13)$ & & $(0.17)$ & $(1.26)$ \\
$\left(0-30^{\circ} \mathrm{N}\right)$ & 0.34 & 1.57 & & 0.92 & 4.11 \\
& $(0.06)$ & $(0.62)$ & & $(0.14)$ & $(2.18)$ \\
$\left(50-30^{\circ} \mathrm{S}\right)$ & 0.51 & 2.74 & & 0.89 & 4.51 \\
& $(0.08)$ & $(0.79)$ & & $(0.27)$ & 3.70 \\
$\left(30-60^{\circ} \mathrm{N}\right)$ & 0.38 & 2.08 & & 0.71 & $(2.09)$ \\
& $(0.09)$ & $(1.11)$ & & $(0.16)$ & \\
\hline
\end{tabular}

The entries in brackets represent the reduction compared to analysis based on monthly zonal mean anomalies.

Table 8. (a) Trend of the differences (in \% per year) for monthly zonal mean total ozone and (b) trend of the differences (in DU per year) for monthly zonal mean total ozone.

\begin{tabular}{lll}
\hline (a) & & \\
\hline Latitudinal zone & GTO minus SBUV & Ground-based minus SBUV \\
\hline$\left(0-30^{\circ} \mathrm{S}\right)$ & $0.05 \pm 0.0098 \% \mathrm{yr}^{-1}$ & $-0.04 \pm 0.0148 \% \mathrm{yr}^{-1}$ \\
$\left(0-30^{\circ} \mathrm{N}\right)$ & $0.05 \pm 0.0090 \% \mathrm{yr}^{-1}$ & $0.12 \pm 0.0160 \% \mathrm{yr}^{-1}$ \\
$\left(50-30^{\circ} \mathrm{S}\right)$ & $0.07 \pm 0.0097 \% \mathrm{yr}^{-1}$ & $0.04 \pm 0.0204 \% \mathrm{yr}^{-1}$ \\
$\left(30-60^{\circ} \mathrm{N}\right)$ & $0.04 \pm 0.0099 \% \mathrm{yr}^{-1}$ & $-0.02 \pm 0.0160 \% \mathrm{yr}^{-1}$ \\
\hline (b) & & \\
\hline Latitudinal zone & $\mathrm{GTO}$ minus SBUV & Ground-based minus SBUV \\
\hline$\left(0-30^{\circ} \mathrm{S}\right)$ & $0.14 \pm 0.0260 \mathrm{DU} \mathrm{yr}$ & $-0.11 \pm 0.0387 \mathrm{DU} \mathrm{yr}^{-1}$ \\
$\left(0-30^{\circ} \mathrm{N}\right)$ & $0.14 \pm 0.0245 \mathrm{DU} \mathrm{yr}^{-1}$ & $0.31 \pm 0.0430 \mathrm{DU} \mathrm{yr}^{-1}$ \\
$\left(50-30^{\circ} \mathrm{S}\right)$ & $0.22 \pm 0.0293 \mathrm{DU} \mathrm{yr}^{-1}$ & $0.12 \pm 0.0617 \mathrm{DU} \mathrm{yr}^{-1}$ \\
$\left(30-60^{\circ} \mathrm{N}\right)$ & $0.14 \pm 0.0330 \mathrm{DU} \mathrm{yr}^{-1}$ & $-0.07 \pm 0.0540 \mathrm{DU} \mathrm{yr}^{-1}$ \\
\hline
\end{tabular}

For the overlap period of 1996 to 2010 , all three data records indicate a gradual increase at $30-60^{\circ} \mathrm{N}$ from $-5 \%$ in 1996 to $-2 \%$ in 2010 . In contrast, at $50-30^{\circ} \mathrm{S}$ and $30^{\circ} \mathrm{S}-$ $30^{\circ} \mathrm{N}$ there has been a levelling off in the 15 years after 1996. The differences in the deviations inferred from GTO and SBUV are depicted in Fig. 10. The results indicate that the differences are between $0 \%$ and $1 \%$ with the exceptions of the dips in 1996 and 2001. In addition, there is a slight increase in the differences during the 15-year period (19962010).

\section{Concluding remarks}

We have presented comparisons of zonal mean total column ozone inferred from three recently released independent multi-year data records. The analyses are based on the 16-year overlap period (March 1996 through June 2011). The results of our investigation have led to the conclusion that, despite the differences in the satellite sensors and retrieval methods, the SBUV v8.6 merged profile total ozone and GTO merged total ozone data records show very good agreement in the monthly mean zonal mean total ozone and monthly mean zonal mean anomalies. The ground-based zonal means, while showing no systematic differences with respect to satellite data records, show larger scatter in the monthly mean data compared to satellite-based records. The scattering is significantly reduced if seasonal zonal averages are analyzed.

The major findings based on the characteristics in the four latitudinal zones $0-30^{\circ} \mathrm{S}, 0-30^{\circ} \mathrm{N}, 50-30^{\circ} \mathrm{S}$, and $30-60^{\circ} \mathrm{N}$ can be summarized as follows:

1. It has been found that, on average, the differences in monthly zonal mean total ozone vary between -0.3 and $0.8 \%$ and are well within $1 \%$.

2. The standard deviations of the differences in monthly zonal mean total ozone for (GTO minus SBUV) vary between 0.6 and $0.7 \%$. The corresponding differences 

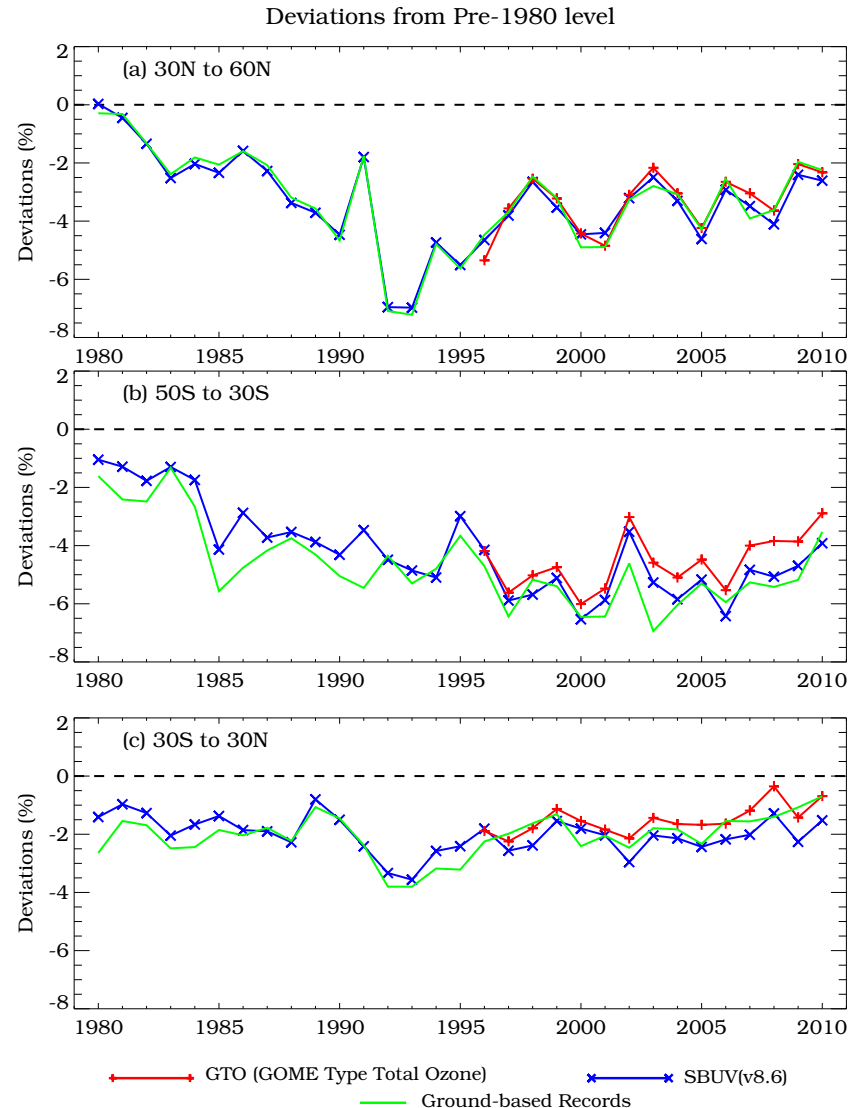

Figure 9. Deviations in annual mean total ozone from pre-1980 levels: (a) $30^{\circ} \mathrm{N}-60^{\circ} \mathrm{N}$, (b) $50^{\circ} \mathrm{S}-30^{\circ} \mathrm{S}$, and (c) $30^{\circ} \mathrm{S}-30^{\circ} \mathrm{N}$.

for ground-based minus SBUV are larger by a factor of 1.4 to 1.9 .

3. The ranges of the differences GTO minus SBUV vary between 2.8 and $3.8 \%$, while the corresponding ranges for ground-based minus SBUV are larger by a factor of 1.4 to 2.4 with values ranging between 5.1 and $6.9 \%$.

4. The standard deviations of differences GTO minus SBUV in monthly zonal mean anomalies vary between 0.4 and $0.6 \%$. The corresponding standard deviations for ground-based minus SBUV are larger by a factor of 1.8 to 2.6 .

5. The ranges of the differences in monthly zonal mean anomalies for GTO minus SBUV vary between 2.2 and $3.5 \%$, while the corresponding ranges for ground-based minus SBUV are larger by a factor of 1.5 to 2.9 with values ranging between 4.4 and $6.3 \%$.

Both the differences GTO minus SBUV and ground-based minus SBUV show no significant trends for the 16-year period indicating the absence of time-dependent differences among the three data records.

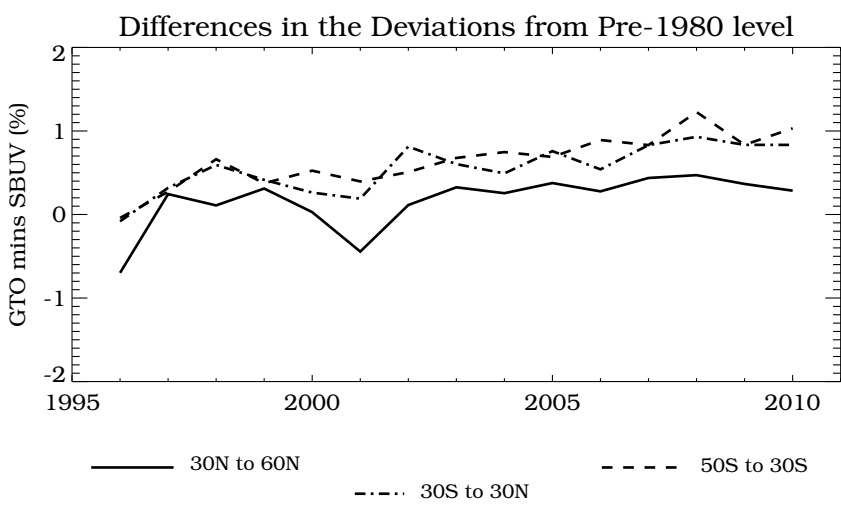

Figure 10. Differences in the deviations from pre-1980 level (GTOSBUV).

Analyses of the annual deviations from pre-1980 level indicate that, for the period of 1996 to 2010 , all three data records show a gradual increase at $30-60^{\circ} \mathrm{N}$ from $-5 \%$ in 1996 to $-2 \%$ in 2010 . In contrast, at $50-30^{\circ} \mathrm{S}$ and $30^{\circ} \mathrm{S}-$ $30^{\circ} \mathrm{N}$ there has been a levelling off in the 15 years after 1996. The deviations inferred from GTO and SBUV show agreement within $1 \%$, but a slight increase has been found in the differences during the 15-year period (1996-2010).

Acknowledgements. E. W. Chiou is supported under NASA Contract NNG12PL17C. The authors would like to thank the TOMS and SBUV instrument team members and WOUDC team members for their work in preparing the SBUV (v8.6) and ground-based data records. The GTO merged ozone data record used in this work was created in the framework of the ESA ozone CCI project. Thanks to ESA for provision of GOME and SCIAMACHY level-1 and level-2 products through DLR D-PAF and D-PAC contracts. We thank EUMETSAT for provision of the GOME-2 level-1 data, and O3M-SAF for operational GOME-2 total ozone products. We also thank the anonymous reviewers for their comments and suggestions.

Edited by: M. Weber

\section{References}

Bhartia, P. K., McPeters, R. D., Flynn, L. E., Taylor, S., Kramarova, N. A., Frith, S., Fisher, B., and DeLand, M.: Solar Backscatter UV (SBUV) total ozone and profile algorithm, Atmos. Meas. Tech., 6, 2533-2548, doi:10.5194/amt-6-2533-2013, 2013.

Bojkov, R. D. and Fioletov, V. E.: Estimating the global ozone characteristics during the last 30 years, J. Geophys. Res., 100, 1653716551, 1995.

Bojkov, R. D. and Fioletov, V. E.: Total ozone variations in the tropical belt: An application for quality of ground-based measurements, Meteorol. Atmos. Phys., 58, 223-240, 1996.

Bowman, K. P.: Global patterns of quasi-biennial oscillation in total ozone, J. Geophys. Res., 99, 3328-3343, 1989.

Dameris, M. and Loyola, D.: Recent and future evolution of the stratospheric ozone layer, in: Atmospheric Physics: Background 
- Methods - Trends, edited by: Schumann, U., Springer, 747762, 2012.

DeLand, M. T., Taylor, S. L., Huang, L. K., and Fisher, B. L.: Calibration of the SBUV version 8.6 ozone data product, Atmos. Meas. Tech., 5, 2951-2967, doi:10.5194/amt-5-2951-2012, 2012.

Fioletov, V. E., Bodecker, G. E., Miller, A. J., McPeters, R. D., and Stolarski, R.: Global and zonal total ozone variations estimated from ground-based and satellite measurements: 1964-2000, J. Geophys. Res., 107, 4647, doi:10.1029/2001JDO001350, 2002.

Frith, S. M., Kramarova, N. A., Stolarski, R. S., McPeters, R. D., Bhartia, P. K., and Labow, G. J.: Recent changes in column ozone based on the SBUV version 8.6 merged ozone dataset, J. Geophys. Res., under review, 2014.

Hamilton, K.: Interhemispheric asymmetry and annual synchronization of the ozone quasi-biennial oscillations, J. Atmos. Sci., 46, 1019-1025, 1989.

Koukouli, M. E., Balis, D. S., Loyola, D., Valks, P., Zimmer, W., Hao, N., Lambert, J.-C., Van Roozendael, M., Lerot, C., and Spurr, R. J. D.: Geophysical validation and long-term consistency between GOME-2/MetOp-A total ozone column and measurements from the sensors GOME/ERS-2, SCIAMACHY/ENVISAT and OMI/Aura, Atmos. Meas. Tech., 5, 2169-2181, doi:10.5194/amt-5-2169-2012, 2012.

Lerot, C., Van Roozendael, M., van Geffen, J., van Gent, J., Fayt, C., Spurr, R., Lichtenberg, G., and von Bargen, A.: Six years of total ozone column measurements from SCIAMACHY nadir observations, Atmos. Meas. Tech., 2, 87-98, doi:10.5194/amt-287-2009, 2009.

Lerot, C., Van Roozendael, M., Lambert, J. C., Granville, J., van Gent, J., Loyola, D., and Spurr, R. J. D.: The GODFIT algorithm: a direct fitting approach to improve the accuracy of total ozone measurements from GOME, Int. J. Remote Sens., 31, 543-550, 2010.

Lerot, C., Van Roozendael, M., Spurr, R., Coldewey-Egbers, M., Kochenova, S., van Gent, J., Koukouli, M., Balis, D., Lambert, J.-C., Granville, J., and Zehner, C.: Homogenized total ozone data records from the European sensors GOME/ERS2,1SCIAMACHY/Envisat and GOME-2/MetOp-A, J. Geophys. Res., 119, D07302, doi:10.1002/2013JD020831, 2014.

Loyola, D. and Coldewey-Egbers, M.: Multi-sensor data merging with stacked neural networks for the creation of satellite long-term climate data records, EURASIP J. Adv. Sig. Proc., 1 doi:10.1186/1687-6180-2012-91, 2012.

Loyola, D., Coldeway-Egbers, M., Dameris, M., Garny, H., Stenke, A., Van Roozendaet, M., Lerot, C., Balis, D., and Koukouli, M.: Global long-term monitoring of the ozone layer-a prerequisite for predictions, Int. J. Remote Sens., 30, 4295-4318, 2009.
Loyola, D., Koukouli, M. E., Valks, P., Balis, D. S., Hao N., Van Roozendael, M., Spurr, R. J. D., Zimmer, W., Kiemle, S., Lerot, C., and Lambert, J. C.: The GOME-2 total column ozone product: Retrieval algorithm and ground-based validation, J. Geophys. Res., 116, D07302, doi:10.1029/2010JD014675, 2011.

McPeters, R. D. and Labow, G. J.: The effect of new ozone cross sections applied to SBUV and TOMS retrievals, Eos Trans. AGU, 91, Meet. Am. Suppl., Abstract A13G-02, 2010.

McPeters, R. D., Bhartia, P. K., Hafner, D., Labow, G. J., and Flynn, L.: The version 8.6 SBUV ozone data record: An overview, J. Geophys. Res., 118, 8032-8039, 2013.

Stolarski, R. S. and Frith, S. M.: Search for evidence of trend slowdown in the long-term TOMS/SBUV total ozone data record: the importance of instrument drift uncertainty, Atmos. Chem. Phys., 6, 4057-4065, doi:10.5194/acp-6-4057-2006, 2006.

UNEP: Handbook for the Montreal Protocol on Substances that Deplete the Ozone Layer, United Nations Envoronment Programme, Secretariat of The Vienna Convention for the Protection of the Ozone Layer \& The Montreal Protocol on Substances that Delpete the Ozone Layer United Nations Environment Programme, Nairobi, Kenya, 2006.

UNFCCC: Kyoto Protocol to the United Nations Framework Convention on Climate Change, Intergovernmental and Legal Affairs, Climate Change Secretariat, Bonn, Germany, 1998.

Van Roozendael, M., Loyola, D., Spurr, R., Balis, D., Lambert, J. C., Livschitz, Y., Valks, P., Ruppert, T., Kenter, P., Fayt, C., and Zehner, C.: Ten years of GOME/ERS-2 total ozone data: the new GOME Data Processor (GDP) version 4: Algorithm Description, J. Geophys. Res., 111, D14311, doi:10.1029/2005JD006375, 2006.

Van Roozendael, M., Spurr, R. J. D., Loyola, D., Lerot, C., Balis, D. S., Lambert, J.C., Zimmer, W., van Gent, J., van Geffen, J., Koukouli, M., Doicu, A., and Zehner, C.: Sixteen years of GOME/ERS-2 total ozone data: The new direct-fitting GOME Data Processor (GDP) version 5 - Algorithn description, J. Geophys Res., 117, D03305, doi:10.1029/2011JD016471, 2012.

WMO - World Meterological Organization: Scientific Assessment of Ozone Depletion:2010, Global Ozone Research and Monitoring Project Report No. 52, Geneva, Switzerland, 516 pp., 2011.

Yang, E. S., Cunnold, D. M., Salawitch, R. J., McCormick, M. P., Russel III, J., Zawodny, J. M., Oltmans, S., and Newchurch, M. J.: Attribution of recovery in lower stratospheric ozone, J. Geophys. Res., 111, D17309, doi:110.1029/2005JD006371, 2006. 